\title{
DEVELOPMENT PROGRAMMES FOR SCHOOL-AGE PERSONS AND PARENTING WORKSHOPS A CHANCE FOR BETTER SELF-EXPRESSION AND IMPROVEMENT OF RELATIONS WITH OTHERS
}

\author{
Agnieszka Solbut \\ University of Biatystok
}

\begin{abstract}
The intention is to present original author's programmes addressed to school-age persons and guardians who wish to improve their parenting skills. The recipients are children and youth from families with alcohol problems as well as their guardians. The problem of alcohol is a deep scratch in the whole family functioning. Unpleasant effects of alcoholism affect all links of the family system. Institutions supporting this type of families respond with an interesting offer of activities the aim of which is gradual overcoming of challenges resulting from the family situation as well as support in full self-expression and improvement of relations with other people through building a strong life base, based on strengths of an individual.

KEYWORDS: alcoholism, dysfunctional family, family relations, preventive programme, development programme, parenting workshops, expression of anger, development.
\end{abstract}

\begin{abstract}
Anotacija
Straipsnyje siekiama pristatyti autorès sukurtas programas, skirtas mokyklinio amžiaus vaikams ir tẻvams, kurie nori patobulinti tẻvystės igūdžius. Programų dalyviai yra vaikai iš šeimų, esančių priklausomybės nuo alkoholio situacijoje, ir tévai ar kiti juos prižiūrintys asmenys. Priklausomybès nuo alkoholio problema palieka gilią žymę šeimos gyvenime. Neigiamą poveikį jaučia visos šeimos sistemos. Tarnybos, padedančios šioms šeimoms, siūlo įdomią veiklos formą, kuria siekiama laipsniškai ịveikti šios situacijos iššūkius, praplèsti saviraiškos galimybes ir sustiprinti tarpusavio santykius taip sukuriant tvirtą asmens stiprybemis pagrịstą gyvenimo pagrindą.

PAGRINDINIAI ŽODŽIAI: priklausomybė nuo alkoholio, disfunkcionali šeima, šeimos santykiai, prevencinè programa, tèvystès įgūdžių užsièmimai, pykčio išraiška, ugdymas.
\end{abstract}

\section{Introduction}

In this article I will present my own original programmes, designed to be executed at the Youth Consultation and Therapy Centre in Białystok which operates at the Day Social Welfare Home in Białystok and from 1997 offers a wide range of support addressed to persons from families with alcohol problems. A group of psychologists and therapists offers specialised help including consultations and psychoeducation, individual psychotherapy, family and marriage therapies. Persons experiencing violence can count on help. Competent support is also found here by persons working with youth, i.e. teachers, educators, superintendents (of 
8 September 2017 Downloaded from: http://www.ddps.rsi.com.pl/mlodziezowyosrodek-konsultacji-i-terapii, 8).

The first programme which I wish to present is addressed to youth. I assumed that working with a young person one should take into account resources of an individual, notice his or her needs, increase self-esteem, i.e. the goal must be optimal development. The development which may be understood as progress and more precisely "a relatively long-term process during which directional changes taking place correctly one after another are made, leading from forms or lower, simpler, less organised stages to more complex, better organised ones" (Matczak 2003, p. 10).

As far as work with persons from families with alcohol problems is concerned, in many cases we are dealing with a failure to meet needs and, as a result, inadequate self-image, rigidity of attitudes, oppositional behaviour or alienation. In response to this diagnostic condition, many preventive programmes are developed addressed to this group of recipients. Many of them focus on correction of disturbed behaviour. While designing my development programme, I assumed that the focus should be on strengthening an individual.

In work with persons from families with alcohol problems, assumptions of the model of help to children from these environments should be kept in mind, i.e.:

1. A child is a part of the family system, therefore help to a child should be a part of the support programme in which a family participates.

2. A child is raised in the family system and help to a child is integrally connected with a family. According the family systemic approach, "in family relations interactions with a spouse are incorporated into the "married couple" subsystem, in contacts with children - into "children" subsystem, etc. In accordance with the general systems theory, it is assumed that an individual, being an element of subsystems, has an active impact on persons he or she interacts with, and is also subject to impact from these persons. Such impact takes place by means of communicative behaviour and is circular in nature. In other words, an individual's behaviour is a reaction to prior behaviour of the partner and constitutes at the same time his or her strengthening and a stimulus for another reactions. To understand behaviour of an individual, one cannot consider it in separation from the social context in which it takes place, i.e. from behaviour of other people" (Grzesiuk 2005, p. 190-191).

3. Help to a child should be planned, based on diagnosis of his or her needs and problems.

4. Help should be complex in nature and therefore include a number of aspects of his or her life. 
5. Help should also be long-term and therefore provided until problems are solved.

6. Help to a child should be individual in nature.

7. Persons providing help should possess appropriate professional knowledge and personal competencies.

8. The support plan should be developed in a team, subject to supervision.

9. Provided help should meet standards adequate to the type of services provided (SAPARP a).

I present below a programme addressed to the youth.

\section{Development programme for school-age children "I express myself calmly, firmly, fearlessly"}

This is an example of my own original programme addressed to enhance emotional and social development of elementary school students with inadequate behaviour.

The programme assumes participation in group sessions. A group consists of up to 6 persons. Meetings last for 45-90 minutes, once a week for 6 months. The programme assumes correction of improper behaviours as well as strengthening and development of the individual's potential and adequate behaviour during sessions.

Recipients: minors 13-17 years of age.

Assumptions explaining the programme. At this stage of a human being development a group of peers is significant. Thanks to group work we create optimal conditions for the development and correction of inadequate behaviour. For young people group work makes it possible to express themselves, confront their experiences with those of their peers. Peer dialogue makes the development of empathy and assertiveness, listening, adequate reacting while others speak or express their criticism easier.

In the period between 12 and 18 years of age an intensive physical and psychological development takes place. A maturing young person learns a new perception of himself for herself and the world. He or she has a sense of increasing importance of his or her thoughts and feelings in shaping his or her own life, planning, and pursuit of objectives. He or she enters wider societal, non-family circles. Emotional independence from parents takes place. A group of peers, which to a large extent meets a number of needs, becomes clearly more important. In addition, a young person becomes skilled in empathy expression. He or she appears in different social roles. He or she develops a hypothetical-deductive 
thinking. Formal operations, self-consciousness are improved. Elements of relativistic thinking can be noticed.

- Coordination of goals and attitudes takes place (Oleszkowicz, Senejkoin: Trempała 2016, p. 283).

- When an individual enters the adolescent period with a sense of confidence, autonomy, initiative and diligence, then pursuant to the 5thstage of the model of personality development according to E. Erickson we will speak of the sense of personal identity, a stage free from role confusion of a child and an adult. In such case we are dealing with being true to oneself and selfconfidence. A failure to resolve all crises related to this development period leads to a feeling of insecurity, lack of personal identity, or even searching for this identity through participation in negative groups of subcultural nature (Pytka 2005, p. 43-44).

In this case, preventive actions themselves will not bring the desired effect. Specific actions are required, such as those presented in the development programme.

Goals of the development programme I express myself - calmly, firmly, fearlessly regard:

- developing an attitude of expressing oneself openly, one's feelings in a calm manner, firmly, without fear;

- correcting anti-social behaviour;

- implementing bold manner of communication FECEB, active listening and speaking;

- implementing in everyday life behaviour alternative to aggressive one;

- developing an adequate self-image;

- developing human capital, intellectual, emotional and social potential of participants.

The programme as sumes the following thematic modules:

Module I Basis of communication. Myself-others

This module is an introduction to the programme. It requires specification of rules binding during sessions. Participants become familiar with principles of dialogic contact. They perform exercises that enable self-presentation, getting to know other participants, build bonds necessary during the whole programme.

Module II Within human feelings, emotions. Anger management.

During this part of the sessions, participants become familiar with the whole range of feelings, emotions. They learn how to express anger. They become familiar with reminders and anger reducers. They become familiar with FECEB, a bold manner of communication, where $\mathrm{F}$ - means facts; $\mathrm{E}$ - means emotions; $\mathrm{C}$ - means 
consequences; E - expectations; B - background, i.e. reference to standards, rules that guide us.

Module III Within social behaviour

Participants learn specific skills necessary in contacts with people which are an alternative to aggressive behaviour. They practice skills selected from the proposed range, e.g. asking for help, responding to harassment, reaction to persuasion, dealing with rejection, accusation, helping others, assertive refusal.

Module IV Within moral interests

Participants solve problems belonging to the category of moral behaviour. During an intra group discussion they come to conclusions, create the message of the sessions regarding major, timeless principles. Moral development of the participants takes place.

An inspiration for the programme presented above was to a large extent the idea of Aggression Replacement Training (ART) developed by Arnold Goldstein, Barry Glink and John Gibbs. ART is used in therapeutic, educational and pedagogical practices. "Combination of four components: complexity, adaptation, taking a situation into account and focusing on feelings show us a concise character of ART" (Winiarska, 2008, p. 294-295; e. g. Goldstein, Glick, Gibbs, 2004).

ART. May be treated as a strategy which, if used correctly, brings positive results in reduction of aggressive, antisocial behaviour.

Success in family relations to a large extent depends on involvement of all parties in the process of improvement or recovery. Hence my idea and the second programme in the form of workshops designed for the Youth Consultation and Therapy Centre and addressed to parents.

An inspiration here was the idea of School for Parents and Educators which was born from the concept of Thomas Gordon, an author of a series of books - Parent Effectiveness Training, as well as the concept of Dr. Haim Ginot, which was promoted in a series of guides by Adele Faber and Elanie Mazlish.

It shall be stressed that the method of School for Parents completely opposes parent's involvement as a dictator, a controller. It does support, however, an adoption by the parent of the role of a friendly advisor, companion who carefully observes a child and his or her surroundings. Thanks to workshops of the School for Parents type, a guardian has a chance to find out that being with a child is possible and may be the source of rewarding experience (Dybowska, 2010, p. 296).

Schools for Parents promote dialogic parent-child contact. A dialogue enables to build understanding between individuals, demolition of walls which perhaps were built for years. The basis for this is nurturing ties between parents and children. A strong bond with parents, guardians' interest in what a child is learning at 
school, regularity in religious practices, respect for standards, rights, social values and authorities are factors that protect a young person from risk taking, making contacts with negative informal groups (Arendarska, Wojcieszek, 2003, p. 31).

Another message of the School for Parents is to love and demand, the same amount of love as demands. It may be assumed that educative relation is complete if there is love as well as there are standards and rules. A parent gradually learns to establish boundaries (Dybowska, Wojtanowicz, 2013, p. 29).

The problem with establishment of boundaries in many cases have persons codependent, experiencing violence, to whom, among others, workshops for parents developed by me are addressed. These are persons whose children have behaviour issues. Often, confronted with family situations they did not have so far either time or strength to improve their parenting skills. Parents qualified for workshops for parents designed by me can be during individual or family therapy.

At this point, it is worth bringing closer what the problem of co-dependency is. The first to deal with the above mentioned issue was Timmen Cermak (a psychiatrist) and Janet Woititz (a therapist). In Poland Bohdan T. Woronowicz (a psychiatrist), Jerzy Mellibruda, Hanna Szczepańska, Irena Pospiszyl were interested in co-dependency.

Codependency is a clinical diagnosis. The following criteria can be distinguished:

- continued investment of self-esteem in the ability to control oneself and others in the face of serious adverse consequences;

- assumption of responsibility for meeting others' needs to the exclusion of acknowledging one's own;

- anxiety and boundary distortions in situations of intimacy and separation;

- enmeshment in relationships with personality disordered, chemically dependent, other co-dependent and/or impulse disordered individuals;

- exhibiting three or more of the following: excessive reliance on denial, constriction of emotions, depression, hyper vigilance, compulsions, anxiety, substance abuse, has been or is the victim of recurrent physical or sexual abuse, stress-related medical illnesses, remaining in a primary relationship with an active substance abuser for at least two years without seeking outside support (SAPARP b).

\section{Parenting Skills Workshops for Building Bridges and Demolishing of Walls Between a Child and a Parent}

In this original programme designed by me in the form of workshops I assumed that the basis for parenting effects is knowledge of a child's needs. 
Behaviour issues are most often reported by parents of children at puberty. This is the period of young people's rebellion, anxiety. An individual learns a different perception of oneself and the world, makes future plans. He or she starts to search for a partner outside the family circle, within one's own generation and develops images of an ideal partner, family, social system and compares them with reality. When an individual enters the adolescent period with a sense of confidence, autonomy, initiative and diligence, he or she has a strong sense of personal identity, does not experience role confusion, inter alia, of a child and an adult. Otherwise, a failure to resolve crises at this development stage leads to a feeling of insecurity and the lack of personal identity.

Crises and conflicts, which are a part of dynamics of life of an individual and a group, can be resolved successfully. Active listening which allows to be successful in the field of parenting is fundamental. However, before a parent starts listening and understanding a child, he or she has to achieve harmony in understanding his or her own emotions, feelings, expectations. A thesis may be assumed that a parent's self-diagnosis is an introduction to work upon himself or herself and further forms a bridge for recognition of the child's needs and problems, to help in overcoming them.

The importance of self-diagnosis was stressed by Ewa Jarosz and EwaWysocka, who said: "If remedial, therapeutic, corrective actions taken as a result of diagnosis are to be effective, they must be based on more or less committed participation of persons, systems, environments they refer to. Such involvement, readiness for cooperation to transform oneself, reduce or overcome existing problems is based on self-awareness of one's own condition, features, deficiencies but also resources" (Jarosz, Wysocka, 2006, p. 26).

Parent's self-awareness is an attitude to motivate oneself and the child to changes. Preparation to enter into adolescence should focus on encouraging children to the best knowledge of themselves, their needs and abilities. The more children know themselves, the more right decisions regarding the future they will be able to take. And this is often what gives their guardians sleepless nights.

A parent is required to be ready to function in dimensions I Parent, I Child, I Adult. Looking through the prism of the child's needs and abilities makes establishment of boundaries and expectations to be met by a child easier.

It shall be assumed that parenting skills require constant improvement.

The workshop on development of parenting skills is intended to:

- become aware of the child's needs;

- understand emotions, one's own and child's feelings;

- express emotions, feelings in a manner that does not endanger anyone; 
- express expectations towards the child;

- develop ways of adequate reactions to the child's aggression;

- interpersonal communication according to FECEB principles;

- motivate the child to act.

The workshop is addressed to parents, legal guardians of school-age children.

Methods used during the workshop: elements of a lecture, a chat, a task - based method, brainstorming, and the six hats method.

Forms of work: individual and group

Detailed topics of the workshop:

Module I - Emotions, feelings, needs

Lesson in Self-awareness

Lesson in Empathy

Lesson in Expression of emotions, feelings and establishing boundaries

Module II - Interpersonal communication

Lesson in Active listening

Lesson in parenting reaction and formulation of expectations

Lesson in motivating a child to change

Both modules, and workshop lessons aim at minimising parental mistakes. Kevin Steede argues that mistakes are made even by good parents because they make efforts which also involve failures. The most important is to be aware of their existence and avoid them in the future (Steede 2000)

Parental failures include instilling incorrect beliefs into a child, such as:

1 mistake - "I have to be good at everything"

A thinking trap of this type is instilled into children when we try to persuade them to take part in classes they are completely not interested in and in a situation when a parent with his or her reaction shows that he or she does not accept performance of the task other than perfectly. It is worth remembering that "support of the child's efforts, and not the level of his or her achievements, will increase self-esteem and motivation to make efforts in the future" (Steede, 2000, p. 22).

2 mistake - "I mean as much as my achievements"

The basis for avoiding such mistake is awareness that it is difficult for children to distinguish the parent's opinion (approval or disapproval) on what they do from assessment of who they are as people. Therefore, the opinion should refer only to behaviour. This is what unconditional love is about. "Children who are loved by their parents un conditionally are feeling safer and their self-esteem is higher. They become more confident of their value and more often begin to rely on their internal abilities" (Steede, 2000, p. 25). 


\section{3 mistake - "Negative feelings are bad"}

The parents' task is to communicate and show with their own example that a man experiences various emotional states and is able to deal with them in a manner which hurts neither himself nor others. However, focusing on negative emotions makes a child perceive himself or herself as different - bad, when this type of feelings occur, he or she starts to suppress them. "Our - parents" goal should be making children aware of their right to their feelings, and strong emotions are completely normal" (Steede, 2000, p. 28).

4 mistake - "All must like me"

The parents' task is to encourage children to rely on their own beliefs and defend their opinion if they are convinced of its rightness, even when facing disapproval or pressure from others. A parent makes children aware of the fact that conflicts are unavoidable and giving up their own points of view they will not stop differences in human opinions. In the face of a difference they have a chance for logic reasoning and presentation of assertive behaviour.

5 mistake - "Making mistakes or asking for help is bad"

Only the atmosphere of support, based on giving a child security, and thus also the right to make mistakes and asking for help, builds an individual's self-esteem. Making mistakes reinforces curiosity, encourages to act to succeed finally, while strengthening a belief that making mistakes and asking for help means incompetence and weakness discourages a child from independent actions and independence in adolescence.

The mistakes listed above occur more often when a guardian enters the role of an authoritarian, preaching, accusing and underestimating parent.

During the workshops parents recognise styles of communication, behaviours typical for the above mentioned types. Playing roles of parents and children, they have a chance to feel as the other party - the opposite entity in the process of upbringing. They learn how to avoid gross mistakes typical for an authoritarian, preaching, accusing and underestimating parent.

An authoritarian parent in communication and the way he or she perceives the needs puts himself or herself above a child. For him or her it is not important what a child feels, thinks or does. His or her role is limited to control. Orders, demands and threats are typical for such parent. In the parent's opinion, feelings are completely useless for a child.

A preaching parent overuses with respect to a child the words - you should, indicating what a child should feel and do. A guardian preaching all the time closes the way for agreement, communication because nobody wants to listen constant instructions. 
An accusing parent stresses that he or she is older and wiser than a child and always right. Such parent is no stranger to sarcasm, insults and humiliation by which he or she decreases a child's value. A child is not a partner in a discussion, and whatever a child does will not satisfy a parent anyway, as a result a child loses an initiative in action.

An underestimating parent on the one hand is afraid of involving his or her feelings in a relation with a child or is busy with other issues. A child has a feeling that a parent does not listen to, does not understand, is not concerned with him or her, i.e. a child is unimportant.

It is worth being aware of the above mistakes to avoid them in everyday life.

During the workshops I adopted Edward de Bono's technique of six thinking hats as a leading method (De Bono, 1998)

The method of six hats consists in focusing on one sort of thinking at a time, e.g. in a moment of specific behaviour issues. Instead of doing everything at once, let's do one thing - just as we put on one hat, then success is more probable, also the one regarding parenting skills. The method of the six hats allows to manage attention, direct it to specific aspects of the issue, certain types of thinking. A participant of the workshops learns this first in a group, to use this method in the future in family life situations, e.g. during family discussions. Edward de Bono encourages to use all hats, i.e. all types of thinking.

Each colour of the hat refers to one type of thinking (De Bono, 1998, p. 74).

White hat: Facts, numbers, data, information. What do we know? What data do we need to obtain?

The white hat means neutral information. We focus here on the available data. The fact is that data and information are important for thinking. Key questions that enable to focus on collecting information are helpful: What data do we already have? What data is missing? How do we get the data we need?

Red hat: Emotions, feelings, hunches, intuition. What do we feel in connection with this case, at the moment we are thinking about it?

The red hat is concerned with our feelings which are an important part of thinking. The task of the red hat is to indicate a place where we can sincerely, without concern reveal our feelings.

Black hat: Caution, assessment of truth, judgement, checking, verification of facts. Are the facts consistent? Will it work? Will it be safe? Is it possible?

The black hat is the hat of critical thinking, protects us against making mistakes. Here we ask ourselves a number of questions, such as: Is it true? Is it right? Will it work? What are the dangers and the problems? 
Yellow hat: Benefits, advantages, profits, savings. Why is this worth doing? What will the benefits be? Why will it be profitable?

The yellow hat is the logic and rational hat, but also full of optimism and hope because it focuses on benefits in a situation. We do not assess all consequences, advantages and disadvantages, we are only interested in benefits.

Green hat: Investigating possibilities, working out, explorations, suggestions, ideas, and innovations. Alternative solutions. What can be done here? What can be done in a different way? Do we have any ideas?

The green hat refers to creative thinking. We can distinguish two meanings of creative thinking:

"1. Creative thinking may mean making something happen, doing things, triggering events. It is similar to constructive thinking. The green hat refers to proposals and conclusions.

2. Creative thinking can also mean new ideas, new solutions, new possibilities, and new inventions. The novelty itself and innovation are important" (De Bono, 1998, p. 87).

Five main applications of the green hat can be pointed out:

1. Knowledge of the situation (investigation).

2. Proposal and suggestions.

3. Alternative solutions.

4. Innovations.

5. Provocative ideas (De Bono 1998, p. 88).

Blue hat: Thinking about thinking. Control and management of the thinking process. Summary.

The blue hat encourages us to look from a higher perspective. We look here for answers to the following questions:

1. Where are we now in our thinking?

2. What is the next step?

3. What is our programme of solving the problem?

4. What have we done so far?

5. Remarks and comments? (De Bono 1998, p. 90).

To sum up, the basis and starting point of presented programmes is understanding and self-awareness in order to understand others better. Improvement of parenting skills within workshops brings the guardians closer to conscious parenthood which is based on lasting relationships with children. To make it possible, it is worth taking into consideration and follow the original pyramid model by Małgorzata Musiał (Musiał, 2017). 
The base of the pyramid of conscious parenthood are boundaries. Going up the pyramid there are emotions, cooperation, conflict settlement and at the very top there are consequences. Taking into account the listed elements promotes building proper relations with children, and this is what the guardians are learning during parenting workshops.

\section{References}

Arendarska, A., Wojcieszek, K. (2003). Preparation of home prevention. Warsaw: SAPARP, p. 31.

De Bono, E. (1998). Teach your child how to think. Warsaw: Prima.

Dybowska, E. (2010). "School for Parents and Guardians” an education to dialogue. In: A. Błasiak, E. Dybowska (eds.). Family pedagogy - selected problems. Cracow: WAM, WSFP „Ignatianum“, p. 296.

Dybowska, E., Wojtanowicz, K. (2013). System of support and forms of work with the family. Cracow: Regionalny Ośrodek Polityki Społecznej, p. 29.

Goldstein, A., Glick, B., Gibbs, J. (2004). ART-aggression replacement programme. Warsaw: Anima.

Grzesiuk, L., Jakubowska, U. (2005). Development and the essence of systemic approach. In: L. Grzesiuk (ed.). Psychotherapy Theoryacademic text book. Warsaw: ENETEIA Wydawnictwo Psychologii i Kultury, p. 190-191.

Jarosz, E., Wysocka, E. (2006). Psycho-pedagogical diagnosis basic problems and solutions. Warsaw: Wydawnictwo Akademickie ,Żak”, p. 26.

Matczak, A. (2003). An outline of the psychology of the development Warsaw: Wydawnictwo Akademickie „Żak”. Musiał, M. (2017). Good relation. A box of tools for the modern family. Mamania.

Oleszkowicz, A., Senejko, A. (2016). Growing up. In: J. Trempała (ed.). Psychology of human development. Warsaw: PWN, p. 283.

Pytka, L. (2005). Social rehabilitation education Selected theoretical, diagnostic and methodical issues. Warsaw: Wydawnictwo Akademii Pedagogiki Specjalnej im. Marii Grzegorzewskiej w Warszawie, p. 43-44.

Steede, K. (2000). 10 Most Common Mistakes Good Parents make. Gdańsk: Gdańskie Wydawnictwo Psychologiczne.

Winiarska, M. (2008). Aggression Replacement Training - ART. In: A. Rejzner (ed.). Violence and aggression at school attempts to resolve the problem. Warsaw: Wyższa Szkoła Pedagogiczna TWP, p. 294-295.

(SAPARP a) State Agency for the Prevention of Alcohol-Related Problems of 8 September 2017. Downloaded from: http://www.parpa.pl/download/rozdzial06.pdf.)

(SAPARP b) State Agency for the Prevention of Alcohol-Related Problems of 8 September 2017. Downloaded from: http://www.parpa.pl/download/rozdzial06.pdf.) 